\title{
Erratum to: Moisture content and decay of differently sized wooden components during 5 years of outdoor exposure
}

\author{
Christian Brischke $^{1} \cdot$ Linda Meyer-Veltrup ${ }^{1}$
}

Published online: 16 October 2015

(C) Springer-Verlag Berlin Heidelberg 2015

\section{Erratum to: Eur. J. Wood Prod.}

DOI 10.1007/s00107-015-0960-7

The original version of this article unfortunately contained a mistake.

The name of the second author Linda Meyer-Veltrup was incorrectly given as Veltrup Meyer.

Moreover, in the References Brischke et al. (2013), Meyer and Brischke (2015), Meyer et al. (2014) and Meyer et al. (2013) the name Meyer V was incorrect and should read Meyer L.

The original article was corrected.

The online version of the original article can be found under doi:10.1007/s00107-015-0960-7.

Christian Brischke

brischke@ibw.uni-hannover.de

1 Leibniz University Hannover, Faculty of Architecture and Landscape Sciences, Institute of Vocational Sciences in the Building Trade, Herrenhäuser Str. 8, 30419 Hannover, Germany 